\title{
O Reino de Israel independente: de Jeroboão I a Zambri
}

Orientadora: Prof ${ }^{a}$. Maria de Lourdes Corrêa Lima

Pesquisador: Willian Gomes Mendonça

Fonte: $\mathrm{CNPq}$

Introdução

A pesquisa sobre os últimos anos do século $\mathrm{X}$ em Israel adotou como fundamento o estudo dos textos bíblicos ao lado dos estudos da arqueologia tradicional e recente. A partir destas três visões, pretendeu-se compreender a perspectiva do autor bíblico ao introduzir a história do nascimento do Reino do Norte a partir do cisma entre Judá e Israel.

\section{Objetivos}

Conhecer melhor a história do antigo Israel e compreender mais adequadamente as intenções e o modo de ler a história presentes no texto bíblico partindo dos dados históricos e arqueológicos sobre as causas imediatas e remotas que constituíram o antigo Israel até a perspectiva peculiar dos textos bíblicos na interpretação da história. 